\author{
Dr. sc. Marin Mrčela, sudac \\ Vrhovnog suda Republike Hrvatske ${ }^{1}$ \\ Dr. sc. Igor Vuletić, docent \\ Pravnog fakulteta, Sveučilišta u Osijeku²
}

\title{
GRANICE NEHAJNE ODGOVORNOSTI ZA KAZNENO DJELO NESAVJESNOG LIJEČENJA
}

\author{
UDK: $343: 61$ \\ Primljeno: 1.3.2017. \\ Izvorni znanstveni rad
}

Kazneno djelo nesavjesnog liječenja ulazi u red medicinskih kaznenih djela stricto sensu. Objekt zaštite kod ovog kaznenog djela jest zdravlje pacijenata koje se štiti od postupaka zdravstvenih radnika koji nisu učinjeni lege artis. Nestručno i nesavjesno postupanje zdravstvenih radnika može imati dalekosežne posljedice, uključujući i smrt. Hrvatska sudska praksa pokazuje da joj takvi predmeti nisu nepoznati. Ipak, hrvatska kaznenopravna literatura je do sada uglavnom zaobilazila ovo vrlo osjetljivo područje, pa je izostala sustavnija rasprava o dometima i granicama kaznene odgovornosti za nesavjesno liječenje. Rješavajući konkretne predmete sudska praksa se može naći u dvojbi oko pitanja pod kojim uvjetima se ponašanje zdravstvenog radnika ima ocijeniti kao nesavjesno, odnosno gdje prestaje odgovornost za nehaj a započinje objektivna odgovornost kod ovog kaznenog djela. Ovaj je rad posvećen upravo toj problematici. Nakon izlaganja općih obilježja ovog kaznenog djela, autori nastoje uspostaviti mjerila za procjenu (ne)postojanja nehajne odgovornosti za nesavjesno liječenje. Svoje teze potom provjeravaju na jednom vrlo složenom predmetu iz novije hrvatske prakse.

Ključne riječi: nehaj, svjesni, nesvjesni, uzročnost, prekid uzročnosti, nepažnja, posljedica, vještačenje, propust

\section{UVOD}

Zaštita zdravlja ljudi ponajprije podrazumijeva zaštitu tjelesnog i psihičkog integriteta bolesnika. U poredbenom zakonodavstvu postoje dva moguća koncepta inkriminiranja takvih ponašanja. Prvi, prema kojem ih se ne regulira u zasebnoj glavi nego se ona kažnjavaju kroz druga kaznena djela (prije svega kao tjelesne ozljede) te drugi, prema kojem se smještaju u zasebnu glavu kaznenog zakona. Hrvatski zakonodavac odlučio je usvojiti koncept prema kojem se kaznena djela, koja su usmjerena na zaštitu zdravlja ljudi, reguliraju u okviru posebne glave. To se

1 Dr. sc. Marin Mrčela, sudac Vrhovnog suda Republike Hrvatske i naslovni docent Pravnog fakulteta Osijek, Sveučilišta J. J. Strossmayera u Osijeku; marin.mrcela@vsrh.hr

2 Dr. sc. Igor Vuletić, docent na Katedri kaznenopravnih znanosti Pravnog fakulteta Osijek, Sveučilišta J. J. Strossmayera u Osijeku; ivuletic@pravos.hr 
opravdava s više argumenata. Navodi se da ta kaznena djela štite integritet posebne skupine osoba (pacijenata i bolesnika), da se tako naglašava odgovornost svih koji sudjeluju u postupcima liječenja ljudi, te da je obavljanje zdravstvene djelatnosti vrlo odgovoran i rizičan posao, koji se mora obavljati s vrlo visokim stupnjem opreza i odgovornosti. ${ }^{3}$ Može se dodati i da je postojanje zasebne glave dobro rješenje zbog toga što se njime postiže veća preglednost i jasnoća propisa, a time $\mathrm{i}$ pravna sigurnost.

Nesavjesno liječenje je u hrvatskom zakonodavstvu inkriminirano kao zasebno kazneno djelo. Time je zakonodavac izrazio stav da pravima pacijenata treba pružiti pojačanu kaznenopravnu zaštitu. ${ }^{4}$ To kazneno djelo ide u red medicinskih kaznenih djela u užem smislu riječi. Njime se štiti zdravlje pacijenata od nestručnih i nesavjesnih postupaka liječnika i ostalog medicinskog osoblja. Naime, nepostupanje zdravstvenih radnika po pravilima struke (lege artis) može imati dalekosežne posljedice po zdravlje bolesnika, a u najgorim situacijama može dovesti i do smrtnog ishoda. Zato se zakonodavac kada pristupa regulaciji tog kaznenog djela uvijek nalazi pred velikim izazovom: s jedne strane, mora postaviti granice odgovornosti dovoljno široko kako bi pružio odgovarajuću zaštitu zdravlja bolesnika; s druge strane, te iste granice ne smije postaviti preširoko i time unijeti pravnu nesigurnost u obavljanje zdravstvenog poziva. Hrvatski zakonodavac je tom izazovu odgovorio tako da je kod normiranja kaznenog djela nesavjesnog liječenja predvidio i nehajni oblik. Upravo taj oblik ponekad izaziva značajne poteškoće u pogledu tumačenja. U rješavanju konkretnih predmeta može se pojaviti dvojba oko pitanja pod kojim uvjetima se ponašanje zdravstvenog radnika ima ocijeniti kao nesavjesno, odnosno gdje prestaje odgovornost za nehaj a započinje objektivna odgovornost kod ovog kaznenog djela. O odgovoru na ta pitanja ovisi i odluka o postojanju ili nepostojanju kaznene odgovornosti. Usprkos tome, ova problematika nije do sada bila u središtu pozornosti hrvatske kaznenopravne literature.

Cilj je ovog rada otkloniti tu prazninu i pokušati uspostaviti usmjeravajuća mjerila utvrđivanja nehajne odgovornosti kod kaznenog djela nesavjesnog liječenja. Rad se sastoji od tri dijela. U prvom se daje općeniti prikaz zakonskih obilježja kaznenog djela o kojem je riječ, kako bi se čitatelja uvelo u problematiku nesavjesnog liječenja. U drugom se dijelu pobliže izlažu pretpostavke nehajne odgovornosti za to kazneno djelo, te se postavljaju usmjeravajuća mjerila koja trebaju poslužiti sudovima u procjeni konkretnih situacija. U trećem se dijelu iznosi vrlo složeni predmet iz novije hrvatske sudske prakse, te se na rezultat, do kojeg su došli prvostupanjski i drugostupanjski sud, primjenjuju predložena mjerila.

3 Roksandić Vidlička, ,Aktualna pitanja pojedinih kaznenih djela protiv zdravlja ljudi“, u: Turković i dr. (ur.), Hrestomatija medicinskog prava, Pravni fakultet Sveučilišta u Zagrebu, 2016., str. 811.

${ }_{4} \quad$ Drukčiji pristup usvajaju npr. njemačko zakonodavstvo, koje opisano postupanje tretira u okviru kaznenog djela teške tjelesne ozljede. Za više v. Hilgendorf, Einführung in das Medizinstrafrecht, C. H. Beck, 2016., 2. poglavlje, rub. br. 3-18. 


\section{ZAKONSKA KONCEPCIJA NESAVJESNOG LIJEČENJA U HRVATSKOM KAZNENOM PRAVU}

Kazneno djelo nesavjesnog liječenja čini doktor medicine, doktor dentalne medicine ili drugi zdravstveni djelatnik, koji obavljajući zdravstvenu djelatnost primijeni očito nepodobno sredstvo ili način liječenja, ili na drugi način očito ne postupi po pravilima zdravstvene struke, ili očito nesavjesno postupa pa time prouzroči pogoršanje bolesti, ili narušavanje zdravlja druge osobe. ${ }^{5}$ Počinitelj ovog kaznenog djela ne može biti svatko nego samo doktor medicine, doktor dentalne medicine i drugi zdravstveni radnik. Drugim zdravstvenim radnicima smatraju se medicinske sestre, medicinski biokemičari i ljekarnici. Iz toga proizlazi da je ovo kazneno djelo koncipirano kao delictum proprium. U krug mogućih počinitelja svrstane su fizičke osobe. Odgovornost zdravstvene ustanove kao pravne osobe se ne spominje u KZ/11., ali ona slijedi iz drugih zakonskih odredbi ${ }^{6}$. Osim toga, odgovornost zdravstvenih ustanova postoji prema propisima iz drugih grana prava ponajprije građanskopravna odgovornost za štetu. ${ }^{7}$

KZ/11. navodi četiri moguća modaliteta radnji ovog kaznenog djela: primjena očito nepodobnog sredstva, primjena očito nepodobnog načina liječenja, očito nepostupanje po pravilima zdravstvene struke ili očito nesavjesno postupanje. Ovdje valja upozoriti kako će se u situaciji u kojoj je ostvareno više radnji počinitelja, suditi samo za jedno kazneno djelo sukladno pravilima o prividnom stjecaju. ${ }^{8}$ Svi navedeni oblici postupanja zapravo bi se mogli podvesti pod nepostupanje po pravilima struke kao širi pojam. Ipak se zakonodavac odlučio za ovakvo nabrajanje kako bi olakšao vještačenje i omogućio preciziranje što se smatra nepostupanjem po pravilima struke. ${ }^{9}$

5 Članak 181. stavka 1. Kaznenog zakona (Narodne novine, broj: 125/11., 144/12., 56/15. i 61/15., dalje u tekstu: KZ/11.)

6 Odgovornost pravne osobe za ovo kazneno djelo postoji prema članku 3. stavku 1. i članku 4. Zakona o odgovornosti pravnih osoba za kaznena djela (Narodne novine, broj: 151/03., 110/07., 45/11. i 143/12.). Pretpostavka za kažnjivost pravne osobe za kazneno djelo odgovorne osobe jest povreda dužnosti pravne osobe. Bolnice su pravne osobe, dapače pravne osobe od posebnog državnog interesa (v. Odluku o popisu pravnih osoba od posebnog državnog interesa, Narodne novine, broj 144/10., 16/14., 55/15. i 105/15.). Bolnička djelatnost obuhvaća dijagnosticiranje, liječenje i medicinsku rehabilitaciju (članak 30. Zakona o zdravstvenoj zaštiti, Narodne novine, broj: 150/08., 71/10., 139/10., 22/11., 84/11., 154/11., 12/12., 35/12. - odluka Ustavnog suda Republike Hrvatske, 70/12., 144/12., 82/13., 159/13., 22/14. 154/14. i 70/16.). Obavljanje tih djelatnosti povjerene su zdravstvenim djelatnicima u zdravstvenim ustanovama koji su stoga odgovorne osobe u pravnoj osobi u smislu navedenih odredbi. Budući da je zdravstvenim djelatnicima kao odgovornim osobama povjereno obavljanje poslova iz područja djelovanja pravne osobe (dijagnosticiranje, liječenje i dr.), to počinjenje kaznenog djela zdravstvenog djelatnika može dovesti i do odgovornosti pravne osobe za to kazneno djelo.

7 V. Turković i dr., Komentar kaznenog zakona, Narodne novine, 2013., str. 240. U poredbenom pravu postoji trend proširivanja kaznene odgovornosti za nesavjesno liječenje i na pravne osobe. Za više o tome v. npr. Brearey-Horne, The Corporate Manslaughter and Corporate Homicide Act 2007 and maternal death: an opportunity to adress systemic deficiences in maternity services?, Cambridge University Press, 2013., str. 210-227.

8 Više o prividnom stjecaju v. Vuletić, „Konsumpcija kao oblik prividnog stjecaja“, Hrvatski ljetopis za kazneno pravo i praksu, 1/2012., str. 15-29.

9 Turković i dr., op. cit., str. 240. 
Postupanje mora biti nesavjesno, ono mora biti protivno opće prihvaćenim pravilima medicinske struke (pisanim i nepisanim) te načelima medicinske etike. U obzir dolaze činjenje (propisivanje neprovjerenih lijekova, primjena pogrešne metode izvođenja nekog zahvata, transfuzija neodgovarajuće krvne grupe i sl.) i nečinjenje (propuštanje poduzimanja potrebnog zahvata, nepoduzimanje potrebnih pretraga, propuštanje dezinficiranja ruku i prostora, previjanje otvorenih fraktura bez prethodne imobilizacije i sl.).

Prilikom ocjene o postojanju spomenutih obilježja treba uzeti u obzir sve okolnosti situacije poput zdravstvenog stanja pacijenta, vrste bolesti, okolnosti i uvjete u kojima je radnja poduzeta i sl. Očito nepodoban način liječenja primijenio je, primjerice, liječnik koji je propustio tražiti laboratorijske pretrage krvi i mokraće, iako je to evidentno zahtijevalo febrilno stanje oštećenika, zbog čega je propustio pravodobno dijagnosticirati leukemiju. ${ }^{10}$ Isto tako, postupila je protivno pravilima struke liječnica koja je, uslijed površno obavljenog pregleda, propustila uočiti simptome sepse, te je oštećenika poslala na kućno liječenje s pogrešnom dijagnozom upale grla i preporukom uzimanja antipiretika. ${ }^{11}$

Za postojanje tog kaznenog djela potrebno je i da poduzete radnje ili propusti dovedu do posljedica. Posljedica se kod temeljnog oblika sastoji u pogoršanju bolesti ili narušenju zdravlja druge osobe. Pogoršanje bolesti postoji kada već ranije postojeće bolesno stanje postane lošije, a narušavanje zdravlja odnosi se prije svega na zdrave osobe. ${ }^{12}$

Za postojanje djela potrebno je dokazati postojanje uzročne veze između radnje počinjenja i nastupjelih posljedica. Uzročna veze bit će isključena ako se utvrdi da je postupak liječnika izveden sukladno pravilima struke. Primjerice, ne postoji uzročna veza između endometriotične ciste desnog jajnika, što je bilo predmet liječenja, i smrti pokojnice, i to stoga što je uzrok smrti karcinom lijevog jajovoda, koji nije bio dijagnosticiran od strane liječnika koji su ranije liječili pokojnicu pa, prema tome, nije ni bio predmetom liječenja od strane optužene liječnice. Ne može joj se staviti na teret niti propust uočavanja karcinoma lijevog jajovoda, jer je ta vrsta karcinoma u praksi iznimno rijetka i vrlo se teško dijagnosticira, najčešće kao slučajni nalaz prilikom operacije. ${ }^{13}$ Jednako tako, uzročna veza može biti isključena i uslijed postupanja oštećenika protivno uputama liječnika. Ne postoji kazneno djelo nesavjesnog liječenja kod liječnice koja je postupala savjesno i uputila pacijenta kojem nije potreban prevoz - neka se sam, u pratnji osobe s kojom je došao, odmah javi na hitni interni prijam, ali pacijent nije postupio prema njenoj uputi nego se na hitni prijam javio tek sljedećeg dana. ${ }^{14}$

10 VSRH, IV Kž-120/91-2.

11 VSRH, Rev 1180/08-2.

12 Tako i Turković u Novoselec (ur.), Posebni dio kaznenog prava, Pravni fakultet Sveučilišta u Zagrebu, 2007., str. 259.

13 VSRH, IV Kž 38/07-2.

14 VSRH, IV Kž 17/12-5. 
Kvalificirani oblici nesavjesnog liječenja postoje ako su opisanim radnjama prouzročene dodatne teže posljedice. Te posljedice jesu teška tjelesna ozljeda ili znatno pogoršanje postojeće bolesti, prouzročenje teške tjelesne ozljede ili prekida trudnoće te prouzročenje smrti jedne ili više osoba. ${ }^{15}$ Ako je prouzročena smrt više osoba, onda je riječ o jednom kaznenom djelu (neće se primijeniti odredbe o stjecaju), ali bi tu okolnost trebalo cijeniti kao otegotnu prilikom odmjeravanja kazne.

Nesavjesno liječenje moguće je počiniti s namjerom i iz nehaja. Namjera je moguća samo u odnosu na nesavjesnost liječenja. ${ }^{16}$ Ona postoji ako je počinitelj svjestan da postupa protivno pravilima struke i želi tako postupati (izravna namjera prvog stupnja), ako je siguran da će određenim postupkom povrijediti pravila struke, pa je taj postupak i poduzeo (izravna namjera drugog stupnja), odnosno ako nije posve siguran da je njegov postupak protivan pravilima struke, ali pristaje i na takvu mogućnost, pa ga svejedno poduzima (neizravna namjera). S obzirom da je nehajni oblik predmet rasprave ovog rada, o njemu će više riječi biti u sljedećem poglavlju.

\section{KRITERIJI UTVRĐIVANJA ODGOVORNOSTI ZA NEHAJ KOD NESAVJESNOG LIJEČENJA}

Ovdje nije nužno raspravljati o osnovnim sastojcima i oblicima nehaja, jer je riječ o općim pravilima. Umjesto toga, rasprava će se usredotočiti na određivanje mjerila procjene nehaja kod kaznenog djela nesavjesnog liječenja. No, prethodno je ipak potrebno upozoriti na dvije vrlo važne stvari koje sudovi moraju imati na umu kada razmatraju pitanje nehajne odgovornosti za ovo kazneno djelo.

Prvo, u odnosu na obilježje nesavjesnosti mogući su i namjera i nehaj. Za razliku od toga, u odnosu na posljedice do kojih je nesavjesnost dovela, moguć je samo nehaj. ${ }^{17}$ Jednako tako te je posljedice pogrešno smatrati objektivnim uvjetima kažnjivosti, jer bi iz toga proizlazilo da one ne moraju uopće biti obuhvaćene počiniteljevom krivnjom, a takvo stajalište je pogrešno. ${ }^{18}$

Drugo, kod ovog djela nije nužno upuštati se u utvrđivanje radi li se o svjesnom ili nesvjesnom nehaju. To proizlazi iz činjenice da razlikovanje svjesnog i nesvjesnog nehaja nije (kao kod izravne i neizravne namjere) kvantitativne nego kvalitativne prirode, te da ima isključivo praktičnu funkciju kako bi se svjesni nehaj lakše razgraničio od neizravne namjere. ${ }^{19}$ Izravna namjera je uvijek teži oblik krivnje

15 Članak 181. stavak 2., 3. i 4. KZ/11.

16 Usp. Turković u Novoselec (ur.), op. cit., str. 260.

17 Ibid.

18 Ibid. Tako i Jescheck/Weigend, Lehrbuch des Strafrecht, Allgemeiner Teil, 5. Auflage, Duncker \& Humblot, Berlin, 1996., str. 583.

19 Tako i Novoselec, koji navodi primjer liječnika koji je na carskom rezu sašio takno crijevo i maternicu i time prouzročio smrt bolesnice. Autor komentira da se tu može konstruirati i svjesni nehaj (liječnik je bio svjestan opasnosti koja postoji kod svakog carskog reza), ali i nesvjesni (nije bio svjestan 
Dr. sc. Marin Mrčela i dr. sc. Igor Vuletić: Granice nehajne odgovornosti za kazneno djelo nesavjesnog.. Zbornik radova Pravnog fakulteta u Splitu, god. 54, 3/2017., str. 685.- 704.

od neizravne, ali to ne vrijedi u odnosu svjesnog i nesvjesnog nehaja. ${ }^{20}$ Zbog toga ne treba gubiti vrijeme na utvrđivanje o kojem se obliku nehaja radi, nego se treba usredotočiti na dvije ključne okolnosti od kojih ovisi stupanj krivnje kod nehajnih delikata. Te okolnosti možemo uzeti i kao mjerila o kojima ovdje govorimo. Ta mjerila su:

1. Postoji li povreda dužne pažnje, odnosno nepostupanje po pravilima struke?

2. Je li zbog toga prouzročena (predvidiva) posljedica za zdravlje bolesnika?

Kaznena odgovornost postojat će samo ako su odgovori na oba pitanja potvrdni. Drugim riječima, kriteriji moraju biti ostvareni skupno.

\subsection{Povreda dužne pažnje/nepostupanje po pravilima struke}

Zdravstvena je djelatnost jedna od onih djelatnosti kod kojih je u svakodnevnom obavljanju uključen povećan stupanj rizika. Gotovo pa svaki medicinski zahvat podrazumijeva manji ili veći rizik za zdravlje bolesnika. Zato se uvijek mora izvan razumne sumnje utvrditi je li posljedica rezultat nesavjesnog postupanja liječnika (medicinske pogreške) ili je do nje došlo zbog naknadnih komplikacija koje se ne mogu pripisati počiniteljevoj krivnji. ${ }^{21}$ Mora se, dakle, raditi o liječničkoj pogrešci kao o postupku protivnom ,pravilima zdravstvene struke i njezinim moralnim $i$ etičkim načelima“. ${ }^{22}$

Da bi postojala nehajna kaznena odgovornost za liječničku pogrešku, posljedica mora proizlaziti iz povrede počiniteljeve dužne pažnje. Pritom se razlikuju unutarnja i vanjska pažnja. Unutarnja pažnja jest dužnost da se predvidi opasnost, tj. da se „razmotre uvjeti pod kojima se poduzima neka radnja i da se predvidi njen tijek“.23 Vanjska pažnja podrazumijeva dužnost da se ponašanje uskladi s prethodnom spoznajom o opasnosti.

U kontekstu nesavjesnog liječenja pravni standard unutarnje pažnje traži da se utvrdi je li liječnik (odnosno, drugi zdravstveni djelatnik) u konkretnoj situaciji uopće prepoznao opasnost. To je potrebno zato što ocjena njegovih daljnjih postupaka

konkretne opasnosti prišivanja organa). Vidi Novoselec, Opći dio kaznenog prava, Peto, izmijenjeno izdanje, Pravni fakultet Osijek, 2016., str. 233. 568.

20 Ibid. Takvo stajalište izražava se i u njemačkoj literaturi. Usp. npr. Jescheck/Weigend, op. cit., str.

21 Tako i Roksandić Vidlička, „Aktualna pitanja pojedinih kaznenih djela protiv zdravlja ljudi“, u: Turković i dr. (ur.), Hrestomatija medicinskog prava, Pravni fakultet Sveučilišta u Zagrebu, 2016., str. 825. Usp. Škavić - Zečević, Načela sudskomedicinskih vještačenja, Naklada Ljevak d.o.o., Zagreb 2010., str. 198. Autori navode da je medicinska pogreška „posljedica očito nesavjesnog postupka” $i$ da je treba razlikovati od komplikacije bolesti „tzv. sudbinski tijek bolesti”. Autori upozoravaju da „svaki postupak liječnika, od dijagnostičkog preko svih oblika liječenja ... nosi u sebi određeni rizik", a riječ je o komplikaciji ,ako zbog postojećeg rizika dođe do štetene posljedice (bez učinjene pogreške liječnika)”.

${ }^{22}$ Klarić, „Odgovornost zdravstvene ustanove i zdravstvenih radnika za štetu“, Hrvatska pravna revija, 9/2001., str. 22.

${ }^{23}$ Novoselec, op. cit., str. 235. 
ovisi o vrsti i mjeri spoznaje o prijetećoj opasnosti. ${ }^{24}$ Mjerilo kojim se pritom treba rukovoditi jest pažnja savjesnog i razboritog liječnika istih kvalifikacija, iskustva i posebnih znanja o konkretnom bolesniku kakva ima počinitelj. Ta se procjena vrši ex ante. Dakle, potrebno je postaviti pitanje kako bi u istoj situaciji postupio npr. prosječni specijalist abdominalne kirurgije s višegodišnjim iskustvom kojemu je poznato da se konkretni pacijent već ranije liječio na njegovom odjelu od točno određene bolesti. Pritom treba voditi računa da se ne upadne u sljedeću zabludu: u zdravstvenoj praksi se povremeno događa da se određeni postupci primjenjuju svakodnevno, iako su protivni uvriježenim protokolima postupanja (pravilima struke $)^{25}$. Ta činjenica ne smije isključiti povredu ulaganja unutarnje pažnje. Naime, zdravstveno je osoblje u svome postupanju dužno pridržavati se pravila struke, a ne običajnih pravila koja su zastarjela, prevladana ili opasna za zdravlje pacijenata. Iz tog razloga se i govori o pažnji ,,savjesnog“ i „razboritog“ liječnika. Dakle, mjerilo utvrđivanja nije „što bi napravila većina“, nego „što je trebalo napraviti“. Zato je iznimno važno da se sud već kod procjene unutarnje pažnje rukovodi prvenstveno pravilima struke koja su bila na snazi u trenutku počinjenja kaznenog djela! Kasnije promjene takvih pravila mogu se uzimati u obzir samo ako idu u prilog počinitelju. ${ }^{26}$ Ako liječnik prilikom postavljanja dijagnoze nije postupio prema pravilima struke, te je zbog toga postavio pogrešnu dijagnozu ili uopće nije dijagnosticirao bolest, znači da je povrijedio unutarnju pažnju, bez obzira na to bi li tako postupila većina liječnika na određenom području. U literaturi se jasno ističe da se ,niži standard pažnje ne može opravdati praksom, koja može biti i dosta raširena, ako se radi o neurednom $i$ aljkavom postupanju,., ${ }^{27} \mathrm{U}$ već spomenutom primjeru liječnik koji je propustio tražiti laboratorijske pretrage krvi i mokraće, iako je to evidentno zahtijevalo febrilno stanje oštećenika, zbog čega je propustio pravodobno dijagnosticirati leukemiju, povrijedio je obvezu unutarnje pažnje.

Ako je odgovor na pitanje o povredi unutarnje pažnje pozitivan, može se prijeći na sljedeći korak - na utvrđivanje je li došlo do povrede vanjske pažnje. Povreda vanjske pažnje podrazumijeva da se daljnje postupanje zdravstvenog radnika prilagodi prethodnoj spoznaji o opasnosti. Pritom treba imati na umu da veći rizik podrazumijeva i veću pažnju, dok s druge strane hitnost nekog zahvata opravdava niži stupanj pažnje. ${ }^{28} \mathrm{Tu}$ se također valja rukovoditi pravilima određene struke. Ponekad će to značiti odustajanje od prerizičnog zahvata, dok se u drugim situacijama zahvat mora poduzeti, ali uz potrebne mjere osiguranja od opasnosti. Primjerice, ako postoje indikacije za carski rez, onda ga se mora poduzeti, ali tako da se pritom vodi računa o izboru one odgovarajuće metode poduzimanja zahvata kojom će se spriječiti mogućnost da se sašiju maternica i tanko crijevo. ${ }^{29}$ Također,

\footnotetext{
24 Usp. Jescheck/Weigend, op. cit., str. 578.

25 Primjerice, Kristellerov zahvat kod poroda (Općinski kazneni sud u Zagrebu, broj K-1291/15.).

26 Klarić, op. cit., str. 21.

27 Ibid, str. 23.

28 Ibid.

29 Novoselec, op. cit., str. 236.
} 
Dr. sc. Marin Mrčela i dr. sc. Igor Vuletić: Granice nehajne odgovornosti za kazneno djelo nesavjesnog.. Zbornik radova Pravnog fakulteta u Splitu, god. 54, 3/2017., str. 685.- 704.

potrebno je obaviti i sve prethodno nužne pretrage i uložiti druge propisane mjere predostrožnosti. Osim toga, savjesno postupanje uvijek uključuje i obvezu jasnog i potpunog informiranja pacijenta te traženja njegovog pristanka prije izvršenja opasne radnje (ex ante). ${ }^{30}$

Kod medicinskih postupaka, koji uključuju više sudionika, važno je obratiti pozornost na još neke okolnosti. Prije svega važno je utvrditi je li raspodjela zadataka bila u skladu s odgovarajućim propisima i pravilima struke. To se odnosi na raspodjelu zadataka između liječnika i pomoćnog medicinskog osoblja te na raspodjelu među liječnicima. Odgovornost za raspodjelu zadataka i praćenje njihovog urednog obavljanja odgovara hijerarhijskoj strukturi određene zdravstvene ustanove. To znači da su nadređeni uvijek odgovorni za odabir suradnika i raspored poslova kao i za izdane upute. S druge strane, treba voditi računa i o načelu uzajamnog povjerenja koje ima svoju okomitu i vodoravnu sastavnicu. Kod vodoravne, nadređeni se može pouzdati u to da će podređeni savjesno izvršiti povjerene zadatke, ako nema indicija da bi oni mogli pogriješiti. Jednako tako, podređeni se mogu pouzdati u točnost uputa i opravdanost naloga, što su ih primili od nadređenih, osim ako su imali indicija posumnjati u njihovu točnost i opravdanost. Ista logika vrijedi i u vodoravnim odnosima, pa se specijalist, koji sudjeluje u operaciji s više drugih specijalista, može pouzdati u njihov savjestan rad. ${ }^{31}$

U pravnoj literaturi navode se različite klasifikacije liječničkih pogrešaka: npr. pogreške činjenjem i nečinjenjem, poduzimanjem neindiciranog ili nepoduzimanjem indiciranog zahvata, pogreške u organizaciji rada, informiranju i sl. Odgovarajuća je klasifikacija važna i praktično, jer o njoj ovisi otkrivanje uzroka pogreške. ${ }^{32} \mathrm{Za}$ potrebe ovog rada prihvatit će se najjednostavnija klasifikacija kojom se razlikuje pogreške u dijagnozi (npr. propuštanje odgovarajuće pretrage kod određenih simptoma, pogrešna interpretacija nalaza ili rendgenskih snimki, pogrešna

30 Ovdje se može postaviti pitanje odgovornosti liječnika ako bolesnik odbije dijagnostički ili terapijski postupak. Članak 16. stavak 1. Zakona o zaštiti prava pacijenata (Narodne novine, broj 169/04. i 37/08., dalje: ZZPP) određuje da bolesnik ima pravo ,prihvatiti ili odbiti pojedini dijagnostički, odnosno terapijski postupak, osim u slučaju neodgodive medicinske intervencije čije bi nepoduzimanje ugrozilo život i zdravlje pacijenta ili izazvalo trajno oštećenje njegovoga zdravlja“. Iz te odredbe slijedi da liječnik mora poduzeti neodgodivi dijagnostički ili terapijski postupak, unatoč bolesnikovu protivljenju, ako bi nepoduzimanje ugrozilo život ili zdravlje bolesnika. No, u literaturi se s pravom upozorava na djelomičnu nesuglasnost ove zakonske odredbe s Europskom konvencijom o zaštiti ljudskih prava i temeljnih sloboda (Narodne novine - Međunarodni ugovori, broj 18/97., 6/99., 14/02., 13/03., 9/05., 1/06., i 2/10.; dalje: EKLJP) i Konvencije o ljudskim pravima i biomedicini (Narodne novine - Međunarodni ugovori, broj 13/03., dalje: KLJPB) - Turković, Pravo na odbijanje medicinskog tretmana u Republici Hrvatskoj, http:// hrcak, srce.hr/medicina. S obzirom na odredbe članka 8. EKLJP-a i članka 26. KLJPB-a, valja razlikovati ugrožava li odbijanje zdravlje ili život bolesnika. Autorica pravilno upozorava da je dio odredbe članka 16. stavka 1. ZZPP-a koji se odnosi na zdravlje suprotan navedenim konvencijama. Drugim riječima, ako se bolesnik protivi intervenciji pa bi nepoduzimanje ugrozilo zdravlje bolesnika, onda liječnik ne smije poduzeti intervenciju. No, ako bi zbog odbijanja došlo do ugrožavanja života bolesnika, onda bi liječnik trebao poduzeti intervenciju jer je ,,pravno sigurnije poštivati odredbu“ članka 16. stavka 1. ZZPP-a u tom dijelu zato što EKLJP i KLJPB ,ne zauzimaju jasan stav glede odnosa između prava na odbijanje liječničkog tretmana i interesa države za očuvanjem života“ (Turković, ibid. str. 169).

31 Tako i Jescheck/Weigend, op. cit., str. 582.

32 Roksandić Vidlička, „Aktualna pitanja pojedinih kaznenih djela protiv zdravlja ljudi“, u: Turković i dr. (ur.), Hrestomatija medicinskog prava, Pravni fakultet Sveučilišta u Zagrebu, 2016., str. 825. 
Dr. sc. Marin Mrčela i dr. sc. Igor Vuletić: Granice nehajne odgovornosti za kazneno djelo nesavjesnog.. Zbornik radova Pravnog fakulteta u Splitu, god. 54, 3/2017., str. 685.- 704.

interpretacija simptoma i sl.) i pogreške u terapiji (ostavljanje predmeta u tijelu pacijenta nakon operacije, zamjena dijelova tijela, primjena pogrešne metode liječenja ili pogrešnog lijeka itd.). ${ }^{33}$

\subsection{Prouzročenje predvidljive posljedice}

Za ostvarenje bića kaznenog djela nesavjesnog liječenja potrebno je da su nastupile određene posljedice za zdravlje ili život pacijenta. Prema težini tih posljedica razlikuje se temeljni od kvalificiranih oblika tog kaznenog djela. Tu je važno napomenuti da će kaznena odgovornost postojati samo ako su te posljedice bile obuhvaćene počiniteljevim nehajem. Naime, obveza ulaganja dužne pažnje, o kojoj je bilo riječi, upravo i postoji zato da bi se otklonilo opasnost nastupa posljedice. Prilikom utvrđivanja nehaja u pogledu posljedica nesavjesnog liječenja treba utvrditi sljedeće:

Posljedica mora biti predvidljiva počinitelju u trenutku (ne)poduzimanja promatrane radnje (ex ante). Potrebno je da je već u tom trenutku posljedica počinitelju poznata (ili mu je morala biti poznata) u svom konkretnom obliku i kauzalnom razvoju događaja. Počinitelja se, dakle, može osuditi samo za one posljedice koje su bile predvidljive na opisani način u trenutku kada je počinio pogrešku. Ako je u tom trenutku već bilo izvjesno da može doći do narušavanja zdravlja ali ne i smrti, onda ga se može osuditi samo za narušavanje zdravlja. To je pitanje posebno složeno kod nesvjesnog nehaja, jer u takvim situacijama počinitelj nije svjestan opasnosti. Zbog toga mjerilo opet treba tražiti u onome što bi predvidio savjestan i razborit stručnjak počiniteljevog profila, koji raspolaže i posebnim znanjima što ih počinitelj ima. ${ }^{34}$ Primjerice, smrtna posljedica nije bila predvidljiva okrivljeniku, koji je kao dežurni kirurg zaprimio alkoholiziranog pacijenta s dva manja defekta na grudnom košu i s jednim na desnoj nadlaktici ali bez krvarenja. Odredio je RTG glave, prsišta i desne nadlaktice, ali na snimkama nije bilo vidljivo zrno, koje je prošlo kroz srčani mišić i u konačnici uzrokovalo smrt. Zrno nije nađeno ni prilikom obdukcije oštećenika. Sâm oštećenik je zbog alkoholiziranosti bio dezorijentiran i nekooperativan, pa se od njega nisu mogle dobiti informacije o načinu povređivanja. Stoga u toj situaciji ništa nije upućivalo na postojanje ozljeda opasnih po život. ${ }^{35}$

Sud mora utvrditi i to je li u konkretnoj situaciji upravo povreda dužne pažnje ta zbog koje je prouzročena posljedica. Za postojanje kaznene odgovornosti je potrebno utvrditi da se upravo opasnost, nastala povredom dužne pažnje, realizirala u posljedici. U tom smislu, treba primijeniti teoriju objektivnog uračunavanja kao

\footnotetext{
33 Klarić, op. cit., str. 24.

34 Jescheck/Weigend, op. cit., str. 587.

35 Županijski sud u Bjelovaru, Kž-100/2015.
} 
vladajuću. ${ }^{36}$ To znači da sud vještaku mora postaviti pitanje bi li do iste posljedice došlo u slučaju da je počinitelj uložio potrebnu unutarnju i vanjsku pažnju.

Problem se može pojaviti kada nije moguće posve sigurno utvrditi bi li posljedica bila sigurno otklonjena u slučaju da je uložena potrebna pažnja. To ujedno otvara i pitanje koji je standard izvjesnosti u tom pogledu potreban. Hrvatska literatura zastupa stajalište da je potreban visok stupanj vjerojatnosti ili vjerojatnost koja graniči sa sigurnošću. ${ }^{37}$ Prema vladajućem mišljenju u njemačkoj literaturi, sukladno pravilu in dubio pro reo, mora se osloboditi od optužbe uvijek kada se izostanak posljedice ne može utvrditi s vjerojatnošću koja graniči sa sigurnošću. To se pravilo dopunjuje teorijom o povišenju rizika (njem. Risikoerhöhungslehre) prema kojoj je potrebno dokazati da je povreda dužne pažnje dovela do značajnog povišenja rizika ugrožavanja objekta radnje. Ako je do takvog povišenja došlo, onda je to dovoljno da se propust smatra uzročnim. U tom smislu, za pravilom in dubio pro reo treba posegnuti samo u situaciji, kada se s vjerojatnošću koja graniči sa sigurnošću, ne može utvrditi je li nesavjesno postupanje uopće dovelo do povećanja rizika. ${ }^{38}$

Ako se prihvati potonje stajalište, onda bi od vještaka trebalo tražiti odgovor na pitanje je li propust u liječenju bio takve prirode da je značajno povećao rizik ugrožavanja zdravlja (ako se radi o narušavanju zdravlja) ili rizik smrtnog ishoda (ako se radi o smrti) kod bolesnika. Treba još napomenuti da uplitanje trećih osoba može predstavljati prekid uzročnosti samo ako te osobe otpočinju posve novi, neovisni uzročni niz. Zato uzročnost postoji i dalje usprkos činjenici da su nakon prvog liječnika i drugi liječnici, koji su liječili pacijenta, počinili istu pogrešku. Svi su oni suuzročnici u nastanku posljedice.

\section{PRIMJENA USMJERAVAJUĆIH MJERILA NA PREDMET IZ SUDSKE PRAKSE}

Na prethodnim stranicama iznesena su dva mjerila kao pomoć za pravilnu procjenu konkretnih situaciju u sudskoj praksi. Treba napomenuti da uspostava takvih mjerila nije jednostavan zadatak jer, s jedne strane, mjerila moraju biti dovoljno apstraktna da se mogu primijeniti na neodređen i nepredvidiv broj situacija dok, s druge strane, mjerila moraju biti dovoljno precizna da dovedu do točnog rješenja. U nastavku teksta provjerit će se jesu li predložena mjerila ispunila tu dvostruku zadaću. Prikazat će se vrlo složen predmet iz novije hrvatske sudske prakse nakon čega će se odluka prvostupanjskog i drugostupanjskog suda podvrći kontroli pomoću predloženih mjerila.

36 Za vrlo iscrpan prikaz teorija uzročnosti v. Martinović, „Problem uzročnosti u kaznenom pravu“, Hrvatski ljetopis za kazneno pravo i praksu, 1/201.2, str. 75-104.

37 Novoselec, op. cit., str. 144.

38 Jescheck/Weigend, op. cit., str. 586. 


\section{1. Činjenično stanje}

Prvostupanjski sud proveo je suđenje i utvrdio činjenice koje su prošle i kontrolu drugostupanjskog suda. ${ }^{39}$ Oštećenica (trudnica) je primljena na Odjel ginekologije KB Osijek 15. ožujka 2004. godine u 6 sati zbog krvarenja nakon spolnog odnosa. Pregled je najprije obavio dežurni liječnik Z. Z., a potom i specijalizantica U. U. ${ }^{40}$ Ultrazvučnim pregledom ustanovljeno je da je plod star 18-19 tjedana i da nema plodne vode u uterusu. Postavljena je dijagnoza kompletnog anhidramnija (nedostatka plodne vode) te su učinjeni osnovni laboratorijski nalazi. Voditelj Odsjeka za sterilitet i infertilitet, optuženi A.A., zatražio je ponavljanje pregleda ultrazvukom, te je nakon toga pacijentici prezentirao stanje trudnoće i rekao kako je potrebno napraviti medicinski inducirani pobačaj. Ona je to odbila i negirala je otjecanje plodne vode. Pitala ga je da li je dijete živo, na što je on odgovorio potvrdno, ali joj je ponovio da trudnoća nije dobra i da treba izvršiti predloženi zahvat. Bilo je vidljivo da pacijentica nije psihički spremna za prekid trudnoće. Nije htjela odlučiti o tome bez konzultacija sa suprugom. U tom trenutku nije bilo moguće utvrditi razlog nedostatka plodne vode. Nakon razgovora, pacijentica je smještena na odjel.

Drugog dana, 16. ožujka 2004., tijekom jutarnje vizite, optuženi A. A. je pacijentici ponovno prezentirao stanje bezizgledne trudnoće, ali je ona zahtijevala da je pregleda šef Odjela ginekologije H. H., što je on i učinio u 13:30, a bio je prisutan i optuženi A. A.. Pregledom je ustanovljeno da je plod živ i star 18-19 tjedana, te da je otvoren cervikalni kanal s nožicom u kanalu uz kompletan anhidramij. H. H. je pacijentici potvrdio dijagnozu optuženog A. A. i predložio inducirani pobačaj. U bolesničkoj sobi, nakon pregleda, optuženi A. A. je ponovno prezentirao pacijentici teško stanje trudnoće koje zahtijeva inducirani pobačaj. Ovoga je puta bio prisutan i njen suprug. U dokaznom se postupku nije nedvojbeno moglo utvrditi jesu li supružnici dali suglasnost za pobačaj. Utvrđeno je da je odluka o tome odgođena za sljedeći dan. U medicinskoj dokumentaciji nije zabilježena preporuka za prekid trudnoće, niti odbijanje prekida trudnoće od strane pacijentice i supruga, ali to proizlazi iz podataka sestrinske bilježnice.

Nakon kraja radnog vremena u 16:00 optuženi A. A. je otišao kući, te su službu preuzeli dežurni liječnici, optužena B. B., kao nadslužba, i optužena C. C., kao srednja služba. Protokol na Odjelu ginekologije KB Osijek bio je takav da se svakog dana u 14:30 održava odjelni sastanak na kojem šef Odjela H. H. iznosi složenije slučajeve i upoznaje s njima dežurnu službu. Naime, na Odjelu je tada bilo svakodnevno smješteno 160 pacijenata zbog čega se dežurnu službu informiralo samo o kritičnim pacijentima. Budući da je stanje oštećenice u tom trenutku bilo stabilno, to ni šef Odjela H. H. a niti optuženi A. A. - nisu smatrali rizičnim stanjem te nisu na slučaj oštećenice posebno upozorili optuženu B. B. i optuženu C. C..

\footnotetext{
39 Općinski sud u Osijeku, 1 K-615/10., Županijski sud u Osijeku, Kž-241/2012.

40 Inicijali procesnih sudionika su promijenjeni.
} 
Optužena C. C. prvi put se s oštećenicom susrela, i upoznala s njenim stanjem, prilikom redovite vizite u 17:00. Iz razgovora s njom doznala je da se pacijentica sprema za zahvat sljedećeg dana. Pacijentica je tada dobro izgledala i nije se žalila ni na kakve bolove, te nije imala temperaturu. Optužena C. C. je također bila upoznata i s činjenicom da pacijentici nije bila uvedena nikakva preventivna antibiotska terapija, niti su joj tog dana rađeni novi laboratorijski nalazi. U 20:00 došlo je do pogoršanja zdravstvenog stanja, pacijentica je dobila temperaturu $38^{\circ} \mathrm{C}$. Optužena C. C. nije u medicinsku dokumentaciju jasno upisala kada je o stanju oštećenice obavijestila optuženu B. B. pa je utvrđeno da je optužena B. B. prvi put za oštećenicu saznala 16. ožujka 2004. u 22:00 sata. Pacijentici je nakon utvrđenja o povišenoj tjelesnoj temperaturi u 20:00 sati dana tableta analgina, te je određeno vađenje osnovnih krvnih nalaza. Oni su stigli poslije 22:00 i pokazivali su pogoršanje stanja, pa je optužena C. C. nazvala optuženu B. B. i obavijestila je o pacijentici te o njenom stanju, a onda i predložila terapiju ketocefom.To je optužena B. B. prihvatila i naložila optuženoj C. C. da prati stanje pacijentice. Nakon toga optužena C. C. više nije obilazila oštećenicu sve do 2:15 kada ju je medicinska sestra pozvala, jer se stanje oštećenice pogoršalo: temperatura je nastavila rasti, imala je krvni tlak 70/60, povratila je, a u jednom trenutku je kolabirala i pala u kupaonici, uslijed čega je moguce da je nastupio razdor jetre što je poslije utvrđeno obdukcijom (nije jasno je li razdor jetre posljedica pada ili reanimacije).

Tada je optužena C. C. u sobu pozvala i optuženu B. B te dežurnog liječnika anesteziologa. Ordinirana je infuzijska terapija, a zbog bolova u stomaku je u 3:30 ordiniran lijek spasmex (po uputi optužene B. B.). S obzirom na to da se stanje oštećenice nastavilo pogoršavati, a bolovi nisu prestajali, to je u konzultacijama s dežurnim kirurgom odlučeno da se napravi snimka abdomena, te je pacijentica u pratnji optužene C. C. odvezena na rendgen u 4:30. Prilikom premještanja pacijentice na kolica, došlo je do zastoja srčanog rada te je započeta reanimacija koja je trajala oko 45 minuta, ali bez uspjeha. Smrt pacijentice proglašena je u 5:15 sati. Kao uzrok smrti utvrđena je infekcija posteljice i plodnih ovoja uz spontani gubitak plodne vode, a to je uzrokovalo bakterimiju, fulminantu sepsu te smrt ploda i jako brz razvoj DIK-a (sindroma intravaskularne koagulacije sa posljedičnim difuznim unutarnjim krvarenjem).

\subsection{Iz nalaza i mišljenja vještaka}

Vještačenje je provelo fakultetsko vijeće Medicinskog fakulteta Sveučilišta u Zagrebu. Izvjestitelj je bio M. M. Iz nalaza i mišljenja proizašlo je da je u postupanju prema oštećenici počinjen niz pogrešaka kliničko-dijagnostičke i organizacijske prirode. Također je proizašlo da je stanje pacijentice bilo ,klinički atipično $i$ većina liječnika, na žalost bi, u Hrvatskoj, postupala identično kao okrivljenici, ali to nije sukladno pravilima struke ". ${ }^{41}$

41 Prvostupanjska odluka, str. 29. 
U odnosu na optuženog A. A., prema nalazu i mišljenju vještaka, propust je u tome što nakon nepristajanja pacijentice na zahvat 16. ožujka 2004. nije učinio kontrolne laboratorijske nalaze koji bi potencijalno ukazivali na mogući razvoj fudrojantnog septičkog šoka i na hitnost zahvata. To je, s obzirom na odbijanje zahvata, bilo neophodno i sukladno pravilima struke, osobito nakon kontrolnog pregleda, koji je obavio šef Odjela u prisutnosti optuženog A. A.. Propust optuženog A. A. je i u tome što nakon odbijanja zahvata nije uveo preventivnu antibiotsku terapiju. Nadalje, propust je i što preporuku, i odbijanje preporuke za pobačaj, nije zabilježio. Konačno, propust šefa Odjela H. H., ali i optuženog A. A. je to što dežurnu službu nisu upoznali sa stanjem pacijentice i označili je kao rizičnu i ugroženu.

Nadalje, vještak je naveo da je optužena C. C. već nakon vizite oko 17:00 bila dužna obavijestiti optuženu B. B. o stanju oštećenice, a i da je sama optužena B. B kao nadslužba bila dužna interesirati se o stanju svih rizičnih pacijenata. Dakle, došlo je do ozbiljnih propusta u komunikaciji između srednje službe i nadslužbe. Tu je komunikaciju trebalo bilježiti i dokumentirati sukladno pravilima. Nadalje, nakon porasta temperature oko 20:00, dežurna služba (optužene B. B. i C. C. u zajedničkim konzultacijama) bila je dužna osim terapije i ketocefa uvesti intenzivniju antibiotsku terapiju gentamicinom i metronidazolom. Već tada se zbog visoke temperature moglo posumnjati na septički abortus, te je trebalo napraviti kompletnu krvnu sliku, CRP i mali koagulogram (obvezne pretrage kod sumnje na septički abortus). Ti nalazi nisu određeni ni kod kasnijeg pogoršanja stanja u 2:15 zbog čega nije uočen razvoj fudrujantne sepse i brzog DIK-a. Također, bolovi u stomaku bili su očiti znak unutarnjeg krvarenja, te je tada trebalo ponoviti krvnu sliku i izvaditi koagulogram, a ne voditi pacijenticu na rendgen. Da se u 20:00 postupalo sukladno pravilima struke, život pacijentice bi gotovo 100\% bio spašen, dok bi i u 02:30 još uvijek postojale realne šanse da bude spašen.

Zaključno, prema nalazu i mišljenju vještaka lege artis postupak bi bio da se oštećenicu, još na dan dolaska, nastojalo nagovoriti na pobačaj, a u slučaju odbijanja zvati i roditelje, i rodbinu, te ih upozoriti na posljedice. Ako bi odbijanje bilo kontinuirano, onda se to moralo zabilježiti, te se svaka četiri sata moralo kontrolirati nalaze i odmah uvesti trojnu antibiotsku terapiju. Također se dežurnu službu trebalo pravodobno informirati o stanju pacijentice te je dežurna služba morala i dalje poduzimati opisane mjere. S obzirom na pogoršanja koja su nastupila, dežurna služba je i bez posebnog upozorenja bila dužna u 20:00 klinički i ultrazvučno pregledati pacijenticu i uvesti adekvatnu terapiju (to je osnovno pravilo struke!) te bolje međusobno komunicirati.

\section{3. Odluka suda}

U pogledu optuženog A. A. sud je utvrdio da je on, doduše, postupao ,ležerno $i$ rutinski, ali ne i nesavjesno, osobito kada se uzme u obzir da je njegovo postupanje 
Dr. sc. Marin Mrčela i dr. sc. Igor Vuletić: Granice nehajne odgovornosti za kazneno djelo nesavjesnog.. Zbornik radova Pravnog fakulteta u Splitu, god. 54, 3/2017., str. 685.- 704.

izričito potvrdio šef odjela“". ${ }^{42}$ Sud je zaključio da se postupak I-okr. ne može okarakterizirati kao nesavjestan zato što je oštećena, u vrijeme dok je on bio zadužen za nju, ,bila dobro raspoložena, nije imala nikakvih vidljivih zdravstvenih pogoršanja“ ${ }^{43}$ On nije imao izričit pristanak pacijentice na predloženi zahvat. Iako je nesporno utvrđeno da je optuženi A. A. morao odrediti kontrolne pretrage 16. ožujka 2004., sud to ne smatra odlučnim zato što je ,njegov propust lako mogao ispraviti šef odjela $H$. H. koji je također pregledao oštećenicu...te smatrao da [optuženi A. A.] nije ništa pogrešno postupio, već je čak iskazao mišljenje da je po pravilima struke..". ${ }^{44}$ Također, ni H. H. nije smatrao da je oštećenica ugroženi pacijent, pa nije o tome izvještavao ni dežurnu službu. Odlučnim sud cijeni zaključak koji, po mišljenju suda, proizlazi iz nalaza i mišljenja vještaka da I-okr. „,nije prouzročio pogoršanje bolesti ... već je samo eventualno mogao provođenjem dijagnostičke obrade potencijalno vidjeti moguć razvojfudrojantnog septičkog šoka i tada pravodobno poduzeti odgovarajuće mjere ". ${ }^{45}$ Pritom se naglašava da se ne može „egzaktno iskazati ${ }^{\text {4t6 }}$ da bi poduzeta obrada doista i ukazala na mogućnost razvoja septičkog šoka. Analizirajući sve dokaze zajedno, i u međusobnoj vezi, sud je zaključio kako provedenim dokaznim postupkom nije nedvojbeno utvrđeno i dokazano da je optuženi A. A. počinio kazneno djelo, koje je predmet optužbe, pa ga je oslobodio od optužbe. Drugostupanjski sud je potvrdio oslobađajući dio prvostupanjske presude te naveo: „... iako iz vještačkog nalaza i mišljenja proizlazi da je propust [optuženog A. A.] što nije učinio kontrolne laboratorijske nalaze, ipak se ti propusti ne mogu okarakterizirati kao grubi propusti koji su očigledno suprotni pravilima medicinske struke i znanosti.“ Drugostupanjski sud još uočava propust ovog optuženika da zabilježi u medicinskoj dokumentaciji sve što je bilo, ali „,da se iz vještačkog nalaza i mišljenja može zaključiti da se propusti [optuženog A. A.] vežu uz činjenicu da je oštećenica odbila dati pristanak [pa] on bez pristanka oštećenice nije mogao izvršiti medicinski inducirani prekid trudnoće“. Osim toga, u vrijeme kada je optuženi A. A. pregledao oštećenicu njeno „stabilno stanje nije ukazivalo na razvoj fudrojantnog septičkog šoka s brzim razvojem DIK-a, a na što se trebalo postumnjati nakon što je oštećenici porasla tjelesna temperatura“" Iako to nije izričito navedeno, nesporno je da optuženi A. A. nije bio u službi kada je oštećenici u 20:00 sati porasla temperatura. Drugostupanjski sud potkrjepljuje utvrđenje prvostupanjskog suda i dijelom nalaza i mišljenja vještaka iz kojeg slijedi „da bi većina liječnika u Republici Hrvatskoj postupilo identično kao okrivljenici“. ${ }^{47}$

U pogledu optužene B. B. prvostupanjski je sud također zaključio da je njeno postupanje bilo rutinsko, ali ne i nesavjesno. $\mathrm{S}$ obzirom na to da se u dokaznom postupku nije moglo sa sigurnošću utvrditi kako je optužena B. B. saznala za stanje

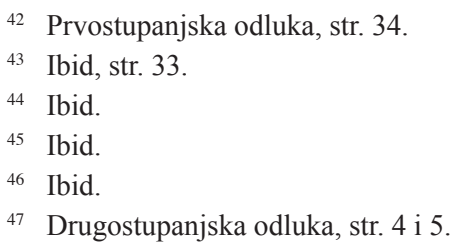


oštećenice već oko 20:00, sud je utvrdio da je ona za to saznala tek u 22:00 kada su izgledi za spašavanje života bili već bitno umanjeni. Činjenica da optužena B. B. nije za to saznala ranije je rezultat pogrešaka ostalih sudionika koji su ranije imali kontakt sa oštećenicom, te loše organizacije posla na Odjelu, a za to optužena B. B. nije bila izravno odgovorna. Kada je saznala za situaciju, tada je optužena B. B. prihvatila terapiju koju je predložila optužena C. C. koja je i sama bila specijalist osposobljen za samostalan rad. Postavlja se pitanje je li prihvaćanjem terapije optužena B. B. postupila nesavjesno jer je u nalazu i mišljenju vještaka istaknuto da je ona zajedno s optuženom $\mathrm{C}$. C. trebala poduzeti intenzivnije mjere liječenja. Osim toga, vještak ističe da je već u tom trenutku optužena B. B. bila dužna osobno pregledati oštećenicu, a to nije učinila nego je odluku donijela na temelju telefonskih konzultacija s optuženom C. C.. Sud na to pitanje odgovara negativno. Naime, sud smatra da u trenutku kad optužena B. B. prihvaća predloženu terapiju, postoji samo vjerojatnost da bi se poduzimanjem adekvatnih mjera spasio život oštećene. Iz toga je sud izveo zaključak da nije nedvojbeno dokazano da je optužena B. B. nesavjesno postupala i propustom u liječenju prouzročila smrt pa je, primjenom pravila in dubio pro reo, oslobodio optuženu B. B. od optužbe. Sud se nije osvrtao na postupanje optužene B. B. nakon 22:00. Drugostupanjski sud je potvrdio oslobađajući dio prvostupanjske presude i u odnosu na optuženu B.B. jer ona o „kritičnom momentu nije imala nikakvih saznanja o oštećenici, ne može niti odgovarati za nesavjesno liječenje“. ${ }^{48}$

U odnosu na optuženu C. C. prvostupanjski je sud utvrdio da je već u 17:00 bila potpuno upoznata sa stanjem oštećenice te da je oko 20:00 bila dužna drukčije reagirati i odrediti kontrolne nalaze KKS-a i malog koagulograma. Ti nalazi bi upućivali na razvoj DIK-a te bi se odmah pristupilo pobačaju i život pacijentice bi bio spašen. Time što je odredila samo osnovne nalaze, postupila je nesavjesno. Daljnja nesavjesnost se ogleda u činjenici da je u 22:00 uvela samo terapiju ketocefom, iako je bilo nužno uvesti intenzivniju antibiotsku zaštitu. Činjenica da je optužena B. B. isto učinila propuste, ne ispričava njenu odgovornost jer je optužena C. C. bila osobno zadužena za oštećenicu. Pogriješila je i što je optuženu B. B. izvijestila tek u 22:00, te što nije slijedila njenu uputu u dijelu da stalno nadzire pacijenticu te je nije više obilazila do $2: 15$, kada joj se stanje već drastično pogoršalo. Kako je utvrđeno da bi postupanje po pravilima struke u 20:00 gotovo sigurno spasilo pacijentičin život, sud je ocijenio da je optužena C. C. postupila nesavjesno, te time prouzročila pogoršanje zdravlja i smrt, pa ju je proglasio krivom i osudio na deset mjeseci zatvora uz primjenu uvjetne osude s vremenom provjeravanja od tri godine. Drugostupanjski sud je potvrdio i osuđujući dio jer je optužena C. C. u 17:00 znala za porast temperature oštećenice čime joj je ,život bio ugrožen [ali] nije prostupila profesionalno i savjesno, jer ona oštećenicu nije niti pregledala, a što je svakako morala učiniti, niti je odredila obavljanje opsežnijih dodatnih krvnih pretraga, niti je obavijestila i konzultirala nadslužbu“ ${ }^{49}$

\footnotetext{
48 Ibidem.

49 Ibidem, str. 7.
} 


\subsection{Primjena usmjeravajućih mjerila na utvrđeno činjenično stanje}

Naposljetku, preostaje primijeniti predložena mjerila i provjeriti bi li se došlo do jednakih rezultata kao u navedenoj odluci. Radi preglednosti, mjerila će se testirati u odnosu na pojedine optuženike odvojeno.

\section{Optuženi A. A.}

\section{Je li povrijedio obvezu dužne pažnje?}

Pri odgovoru na ovo pitanje treba najprije utvrditi jesu li povrijeđena pravila medicinske struke. Iz nalaza i mišljenja vještaka nedvojbeno proizlazi potvrdan odgovor, jer optuženi A. A. nije odredio kontrolne laboratorijske nalaze, uveo preventivnu antibiotsku terapiju i zabilježio preporuke i njihovo odbijanje.

Potom treba utvrditi je li uopće prepoznao opasnost (unutarnja pažnja). Više je puta upozorio pacijenticu da je potrebno izvršiti pobačaj, te da može imati komplikacije. Iz toga se može zaključiti kako je optuženi A. A. bio svjestan opasnosti, odnosno da u slučaju nepostupanja može doći do pogoršanja zdravstvenog stanja.

Sljedeće pitanje odnosi se na ulaganje potrebne vanjske pažnje, odnosno je li optuženi A. A. svoje daljnje ponašanje prilagodio prethodnoj spoznaji o opasnosti situacije. Iz nalaza i mišljenja vještaka proizlaze povrede pravila struke: propust poduzimanja odgovarajuće terapije bez obzira na to što oštećenica u 16:00 nije imala povišenu temperaturu, bilježenje poduzetog i obavijest hitnoj službi, koja preuzima dužnost nakon njegova odlaska iz bolnice. Okolnost da pretpostavljeni čini jednaki propust, ne potire odgovornost ordinirajućeg liječnika. Jednako je pravno beznačajno kako bi većina liječnika postupila u konkretnoj situaciji, jer su usmjeravajuća mjerila pravila struke, a ne (pogrešno) postupanje većine. Iz navedenog se može zaključiti da je postupak bio nesavjestan, a ne samo „ležeran“ i „rutinski“. Pritom potonje nazivlje nije pravno i nije bilo nužno utvrđivati je li postupanje takvo, nego je li konkretno postupanje bilo očito nepostupanje po pravilima zdravstvene struke, ili očito nesavjesno. No, povreda pravila struke, povreda unutarnje i vanjske pažnje još nije dostatna za uspostavljanje nehajne odgovornosti. Za kaznenu odgovornost potrebno je još i to navesti - da je opisanim propustom prouzročena predvidljiva posljedica.

\section{Je li prouzročena predvidljiva posljedica?}

Za odgovor na to pitanje bilo bi presudno utvrditi je li optuženi A. A. u trenutku nepoduzimanja dužnih radnji bio svjestan, ili je li mogao i morao biti svjestan da s vjerojatnošću, koja graniči sa sigurnoću, mogu nastupiti posljedice u vidu pogoršanja zdravlja i smrti. Takvo pitanje vještaku nije decidirano postavljeno. Ipak, iz nalaza i mišljenja, vidljivo je da bi nalazi pravodobno određenih laboratorijskih pretraga mogli uputiti na hitnost pobačaja. S obzirom na to da je optuženi A. A. specijalist ginekologije s dugogodišnjim stažom, mogao je - sa svojim kvalifikacijama, 
znanjem $\mathrm{i}$ iskustvom - $\mathrm{i}$ trebao znati da nepoduzimanjem tih pretraga stvara opasnost za zdravlje pacijentice, jer propušta postaviti potpunu i ispravnu dijagnozu. Također je, s obzirom na svoje iskustvo, morao znati da propuštanje pravodobne $\mathrm{i}$ točne dijagnoze, a osobito preventivne terapije, može imati vrlo vjerojatno, gotovo sigurno - opasnost po život oštećenice, odnosno smrtni ishod. Stoga i na pitanje o svijesti o mogućnosti nastupanja posljedice, treba dati pozitivan odgovor.

Naposljetku, treba utvrditi i to je li propust prouzročio posljedicu. Upravo tu okolnost sud cijeni kao ključnu kada navodi da on nije prouzročio pogoršanje bolesti, jer je pravodobnom reakcijom eventualno mogao vidjeti razvoj septičkog šoka, kao $\mathrm{i}$ da je isti taj previd napravio i njegov pretpostavljeni $\mathrm{H}$. $\mathrm{H}$. U pogledu doprinosa treće osobe (ovdje osoba H. H.) treba ponoviti da on ne utječe na isključenje krivnje kod optuženika. U pogledu uzročne veze između propusta i konačne posljedice, treba posegnuti za već spomenutom teorijom rizika i upitati se je li povreda propisane procedure postupanja dovela do značajnog povišenja rizika za zdravlje i život pacijentice. Na temelju mišljenja vještaka da je pacijenticu već prilikom prijema u bolnicu trebalo okvalificirati kao ugroženu, te da bi pravodobno učinjeni nalazi potencijalno indicirali razvoj sepse i nužan prekid trudnoće radi spašavanja života oštećenice - pravilno je zaključiti da je nepostupanje dovelo do značajnog povećanja rizika. Iz navedenog slijedi da je nečinjenjem (čemu se pridružio i $\mathrm{H}$. H. koji nije optužen) započeo kauzalni tijek događaja koji će u konačnici dovesti do pogoršanja zdravlja i smrti. Pogreške u liječenju, kako to slijedi iz vještačkog nalaza i mišljenja, koje su učinjene poslije, proizašle su upravo iz činjenice da dežurna služba nije na odgovarajući način bila upozorena o stanju pacijentice i nije raspolagala potpunim nalazima.

\section{Optužena B. B.}

\section{Je li povrijedila obvezu dužne pažnje?}

Polazi se od utvrđenja da je o čitavom slučaju obaviještena tek oko 22:00, kada je stanje pacijentice već bilo znatno pogoršano, a mogućnosti spašavanja života umanjene. Postoji li povreda pravila struke? Iz utvrđenog činjeničnog stanja proizlazi da se kod srednje službe nije samoinicijativno interesirala o posebno ugroženim pacijentima, a to postupanje je protivno pravilima struke. U trenutku kad je obaviještena o stanju pacijentice te u daljnjem razvoju događaja, također nije bilo postupanja po pravilima struke, jer nije određena intenzivnija antibiotska terapija niti kontrolne pretrage, a također optužena B. B. nije prepoznala ni bolove u stomaku kao simptom unutarnjeg krvarenja što bi, prema mišljenju vještaka, trebao moći prepoznati svaki licencirani ginekolog. Stoga je odgovor na ovo pitanje pozitivan.

Je li prepoznata opasnost (unutarnja pažnja)? S obzirom na činjenicu da je prihvatila ,telefonski“" prijedlog terapije i nije inzistirala na daljnjim kontrolnim pretragama, te da je i poslije odlučila uputiti pacijenticu na rendgen, umjesto 
ponoviti krvnu sliku i izvaditi koagulogram - logičan zaključak bi bio da optuženica nije prepoznala opasnost u punom opsegu. Taj zaključak je tim vjerojatniji što je kliničko stanje bilo atipično. Ipak, vještak smatra da je optužena B.B ,mogla $i$ morala prepoznati “50 stanje oštećenice i moguće komplikacije. Zato se može zaključiti da nije uložila potrebnu unutarnju, a time ni vanjsku pažnju.

\section{Je li prouzročena predvidljiva posljedica?}

Iz nalaza i mišljenja vještaka je očito da bi drukčije postupanje dežurne službe spriječilo nastupjelu posljedicu. Konkretno, da je optužena B. B. u 22:00 (makar je samo telefonski obaviještena o tada već po život opasnom stanju oštećenice) dopunila terapiju predloženu od strane optužene C. C. te odredila kontrolne pretrage u 22:00, tada kad je saznala za stanje pacijentice - postojala je još uvijek ,realna šansa“, prema nalazu i mišljenju vještaka, da bi time spasila život oštećenice. Zato bi odgovor na ovo pitanje bio pozitivan.

\section{Optužena C. C.}

\section{Je li povrijedila obvezu dužne pažnje?}

Optužena C. C. je bila u neposrednom kontaktu s pacijenticom od 17:00. Prethodna izlaganja upućuju na zaključak o povredi pravila struke. U pogledu pogrešnih dijagnostičko-terapijskih postupaka vrijedi jednako kao i za ostale optuženike. Krivnju ne isključuje okolnost što su previde imali stariji i pretpostavljeni kolege, jer bi postupanje po pravilima struke u 17:00 vjerojatno, gotovo pa sigurno, spriječilo neželjenu posljedicu. Osim toga, okolnost nevođenja uredne medicinske dokumentacije o slučaju, također predstavlja nepostupanje po pravilima struke.

U pogledu pitanja o unutarnjoj pažnji, proizlazi da je optužena C. C. bila svjesna postojanja potencijalne opasnosti po život i zdravlje pacijentice u 20:00, jer je tada, uslijed porasta temperature, odredila tek analgin, ali nije naručila laboratorijske pretrage. Oko 22:00 očito postaje svjesnija opasnosti, jer obavještava stariju službu, predlaže (nedostatnu) terapiju te određuje osnovne laboratorijske nalaze. Bez obzida na to, ostavlja oštećenicu bez nadzora sve do znatnog pogoršanja stanja u 02:15. Iz svega proizlazi da je njena unutarnja pažnja postojala barem djelomično. Sukladno tome, njena vanjska pažnja nije bila odgovarajuća, a to i proizlazi iz nalaza i mišljenja vještaka.

\section{Je li prouzročena predvidljiva posljedica?}

Iz nalaza i mišljenja vještaka što ga sud prihvaća, jasno i nedvojbeno proizlazi da je optužena C. C. svojim propustima postupanja po pravilima medicinske struke i općenito nesavjesnim postupanjem prouzročila smrtnu posljedicu oštećenice.

50 Općinski sud u Osijeku, 1 K-615/10., str. 29. 
Dr. sc. Marin Mrčela i dr. sc. Igor Vuletić: Granice nehajne odgovornosti za kazneno djelo nesavjesnog.. Zbornik radova Pravnog fakulteta u Splitu, god. 54, 3/2017., str. 685.- 704.

Zato odluku u ovom dijelu nalazimo pravilnom imajući na umu činjenična i pravna utvrđenja te izložena usmjeravajuća mjerila. ${ }^{51}$

\section{ZAKLJUČAK}

Ovaj predmet iz sudske prakse zorno pokazuje složenost i važnost dometa nehajne odgovornosti za kazneno djelo nesavjesnog liječenja. Čitavo medicinsko kazneno pravo, a osobito kazneno djelo nesavjesnog liječenja, predstavlja veliki izazov za sudsku praksu. Osobito se to odnosi na razgraničenje bitnih od nebitnih činjenica i njihovo pravilno i potpuno utvrđivanje. Za to će uvijek biti potrebno konzultirati jednog ili više vještaka. Zbog toga je presudno da sudska praksa ima na raspolaganju jasna mjerila koja usmjeravaju ovu složenu intelektualnu djelatnost $\mathrm{i}$ pomažu kod donošenja pravilne odluke.

S druge strane, prikazani predmet upućuje i na važnost poznavanja osnova medicinskog kaznenog prava od strane zdravstvenih radnika (i svih ostalih koji su uključeni u zdravstvene procese i odgovorni za organizaciju rada, poput uprava bolnica i sl.). Iz izložene rasprave je očito da u zdravstvenoj praksi postoje određene zablude u pogledu pravilnog načina postupanja, gledano iz perspektive kaznene odgovornosti. Imajući to na umu, ovaj rad je imao za cilj ne samo ponuditi usmjeravajuća mjerila za sudsku praksu nego i upozoriti zdravstvene radnike na pravilan način postupanja čime ne podliježu kaznenoj odgovornosti, a još važnije i sprječava se nastupanje zabranjenih i neželjenjih posljedica određenih u članku 181. KZ/11.

Sudskoj praksi su predložena jasna i jednostavna mjerila koja se u osnovi sastoje u pravilnom i točnom tumačenju općih pravila o nehaju (povreda dužne pažnje/ postupanje po pravilima struke i prouzročenje zabranjene posljedice). Primjenom tih mjerila na predmet iz novije hrvatske sudske prakse iskušane su teorijske postavke na životnoj situaciji. Usmjeravajuća mjerila su razjašenjena i ona mogu pomoći kod utvrđivanja odlučnih okolnosti te dovesti do pravilnog i potpuno utvrđenog činjeničnog stanja. Treba napomenuti da u dosadašnjoj hrvatskoj kaznenopravnoj literaturi nesavjesnom liječenju nije pristupano na ovako konkretan i empirijski provjerljiv način, pa je za vjerovati da će zaključci ovog rada biti korisni, ne samo za teoriju, nego i za sudsku praksu pri susretanju s konkretnim problemima.

Naposljetku, određene pouke mogu se izvući i za zdravstvene radnike. Oni nisu pravnici i od njih se nipošto ne zahtijeva visoka razina poznavanja prava. Ipak, s obzirom na to da se zdravstveni radnici bave posebnom vrstom djelatnosti, reguliranom posebnim propisima, od njih se može i mora očekivati poznavanje tih propisa, a osobito pravila struke. Potonja pravila osiguravaju da se zdravstvena profesija odvija sigurno i uz minimalni rizik, kako za bolesnike, tako i za same

51 Presuda koja je ovdje izložena donesena je nakon ponovljenog suđenja. U prethodnom postupku bila je donesena osuđujuća presuda za sve optuženike, ali je ta odluka ukinuta (Općinski sud u Osijeku, I-K-502/07-58). 
zdravstvene radnike. Ulaženje u konkretna pravila svakog od mnogih područja zdravstvene struke, te propisa koji reguliraju ta područja, prelazi granice ovog rada. Zato se tek upozorilo na nekoliko glavnih zabluda i na ispravno postupanje. Ono treba spriječiti pogrešno postupanje koje vodi do nastupanja neželjenih posljedica, a time i do kaznene odgovornosti zdravstvenog radnika. Te zablude i upute za postupanje mogu se svesti na sljedeće. Prvo, pri obavljanju zdravstvene djelatnosti uvijek je potrebno pridržavati se pravila struke. Ona su sadržana u odgovarajućim protokolima i uvijek imaju prednost pred uhodanim procedurama i raširenom praksom. Postupanje većine ili nadređenog ne ispričava, ako je ono suprotno pravilima struke. Drugo, o svemu što se radi potrebno je voditi ažurnu medicinsku dokumentaciju, jer je pisani trag, gotovo pa uvijek, pouzdan dokaz u kaznenom postupku. Treće, pogreška koju počini ili ponovi drugi kolega, pa bio on stariji, iskusniji i nadređen, ne oslobađa kaznene odgovornosti, osim ako ne predstavlja početak zasebnog kauzalnog tijeka koji dovodi do zabranjene posljedice.

\section{LIMITS OF NEGLIGENT RESPONSIBILITY FOR MEDICAL MALPRACTICE}

Criminal offence of medical malpractice is one of core medical criminal offences. Protected object is health of patients. Application of inadequate methods in health treatment can have severe consequences for patient's health, even death. Croatian jurisprudence is familiar with such cases. However, Croatian literature until now did not deal with this sensitive area of criminal law. Scope and limits of responsibility for negligent form of medical malpractice can cause doubts in court's practice when deciding about criminal liability. This paper is dedicated to this topic. After presentation of main characteristics of this criminal offence, the authors are making an effort to establish criteria for estimation of negligence in case of medical malpractice. They are testing their thesis on one very complicated case from recent Croatian jurisprudence.

Key words: negligence, aware, unaware, causality, interruption of causality, inattention, consequence, expertise, ommision 